\title{
The Performative Manifestation of a Research Identity: Storying the Journey Through Poetry
}

\author{
Jennifer L. Lapum
}

\section{Key words:}

research identity, performative, poetry, narrative, reflexivity, photography, positionality, paradigm

\begin{abstract}
Cultivating a research identity is an arduous journey. We are told to situate ourselvesknow where we are coming from-but it is rare that people share their experiences and provide insight into a journey that indubitably shapes your research. In this performative piece, I shed light on my journey to a research identity. I provide an intimate portrayal of the blurring and temporal nature of research identities that is sometimes avoided and often unaccepted. In doing so, I hope to awaken new understandings and provide insight into what can be a direction(less) journey that leads to a sense of positioning. My journey is a tracing rendered through poetry-enhanced prose, which provides aesthetic sensibilities and the possibility for you to enter into and become caught up in our experience. As well, poetry and photography are bestowed in a way to illuminate the performative and dynamic place of my research identity and as a way to visualize and feel the story within this poetical telling. This is a manifestation of performative social science in which the voice is never solely mine and the identity is never conclusive as it continues to unfold and shift through the spaces I inhabit.
\end{abstract}

Table of Contents

1. Prologue

2. Background: Research Identity

3. A Forethought: Poetry

4. Unearthing the Performative

4.1 Edging away from the dominant discourse

4.2 Gravitating to postmodernism

4.3 Tailor-made research identity

$\underline{4.4} \mathrm{~A}$ trial curtain call

4.5 Performative: The "bottom" line

4.6 My unfinalizability

Acknowledgments \& Attribution Statements

References

Author

Citation 


\section{Prologue}

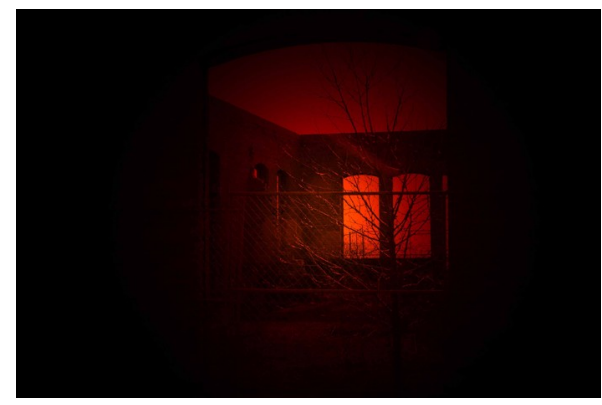

Illustration 1: Reviving subtleties of self @ Gary C. BARJAROW, 2006 [1]

The indifference of a being

begets complacency

begets emptiness

letting annihilation flourish-

in the face of nothing,

estranged from your own life

feeding the passive cosines of your own soul

the spurious ways that catch you up, still,

the presence of neglect hovers

like darkness deceptively woven into an incandescent structure

bareness only breeds bareness

quite dismal when,

you forget how to achromatize rose-colored glasses

seeing the way you think they want you to be

the hidden insanity

raising its ugly head

heeding the apathetic

can we even remember

how to revive subtleties of self

resuscitate childhood virtues

peel open the door that has been fastened for too long seek and wonder and wander the places

that are not on the map

awaken the mud dripping lotus [2] 
To remain under the ostensible, auspicious nature of rose colored glasses. To stay unknowing — to remain indifferent to your research identity - to conduct research without first understanding self (see Illustration 1). It would take far less effort to conceal this journey to a research identity, to mask its existence, to keep it implicit—-that is why I call this performative piece a confession, something I disclose, something that is normally obscured. It is uncomfortable to show my vulnerabilities, but to make this journey explicit disencumbers me from the ramifications of indifference. [3]

This is a poetical narrative of my journey to cultivating a research identity that fits my way of thinking, my being, and is congruent with both my methodological orientation and my substantive research phenomenon. I could have attempted to state concisely my research identity, but it is the journey that explicates the temporal and performative nature of identities. [4]

The performative nature of a journey to a research identity is narrated in a way that it "enacts, performs, and evokes, rather than conveys" (NOY, 2003, paragraph 49). Performativity is not a mere telling, but is an actual showing and being in the world that is moral and dialogical as a researcher (DENZIN, 2001). Performativity stretches across a broad range of fields including, but not limited to language studies, geography, history, sexual identity, queer theory, performance studies, drama, and the social and health sciences. A performative social science loosens the focus on an objective stance and provides space for the dialogical construction of knowledge (JONES, 2006). The journey I took to a research identity was unintentionally performative. I was encouraged to look inward before I looked outward, to look inward as I looked outward. As we consider the interpretive nature of qualitative inquiry, it is critical to situate self and make transparent presuppositions because these shape how the researcher "sees the world and acts in it" (DENZIN \& LINCOLN, 2000, p.19). As I enacted my research identity, I took an unfamiliar path that led me in many different directions (see Illustration 2). It was through the performative that my identity was built. [5]

Establishing a research identity began as somewhat of a prodigious obstruction to developing and conducting my doctoral research. The purpose of my study was to understand patients' experiences of technology in heart surgery in order to enhance practitioners' ways of thinking. 


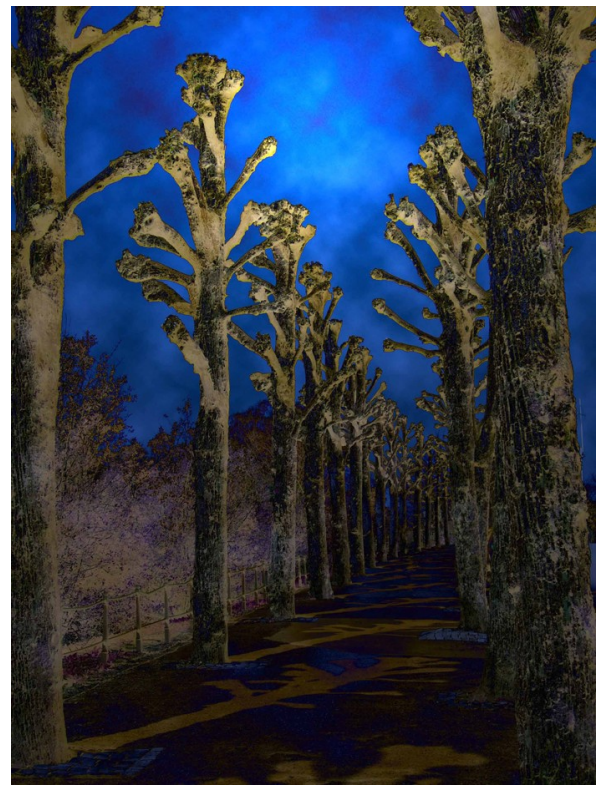

Illustration 2: Unfamiliar @ Jennifer L. LAPUM, 2006 [6]

and practice. Patients' experiences of heart surgery have been looked at before, but how they constructed technology in their stories was not an explicit focus of the existing research. Initially I did not clearly know where I was going, how I would get there, or where I would end up. It was a daunting journey, but it was also captivating and revealing. This journey can often be isolating, confusing and paralyzing. I have often found myself commiserating with others as a way to clarify and refine my thinking, and as a way to move beyond some of these paralyzing moments. I pushed forward, backward, inward and outward, challenged my assumptions, and transcended habitual ways of thinking. [7]

In this article, I restory a poetical confession of my journey to untangling and explicating my research identity, making this journey transparent, and sharing it with others. I shed light on a journey that is commonly undisclosed by researchers or just not undertaken at all. It is only in writing this journey that I understood the discursively-shaped construction of identities and enacted and embodied my identity more fully. By sharing in our journeys to research identities, we may help each other to un-paralyze self. Manifest in my poetical telling are possibilities for the temporal and blurring nature of research identities that is sometimes avoided and/or unaccepted. This article could be considered what GUBA and LINCOLN (2005) call a postmodern representation in which I experiment with the boundaries of the social sciences and create a non-linear and messy text through narrative, poetry and photography. To qualify, this is not a didactic article. Rather, I ask you (the reader) to join me in my journey to a research identity, to engage in it, feel it, become emotionally drawn in, and intellectually perplexed. You are invited into the text to resonate, to story further, to flesh out your own identity, and possibly, to critique and challenge the underlying assumptions that drive my journey. The main objectives are to engage 
you dialogically and performatively and invite you to wonder about and wander into the journey to a research identity. [8]

\section{Background: Research Identity}

Because of persistent positivistic persuasions, researchers tend to be cautious in revealing how assumptions shape their research (COX, 2003). Published reflexive accounts are neglected by authors as a way to elude criticism and scrutiny. Nevertheless, research is never neutral and unbiased (HAMMERSLEY \& ATKINSON, 1989; MANDERSON, BENNETT \& ANDAJANI-SUTJAHJO, 2006). Generally, researchers attend to an abstract framework, be it philosophical or conceptual (implicit or explicit), which influences interpretations and findings (CAROLAN, 2003; SANDELOWSKI, 2000). It is important to draw attention to this framework so others have a sense of how the researcher is seeing and interpreting data. Often, qualitative researchers will align themselves with one of the paradigms laid out by GUBA and LINCOLN (2005). Paradigmatic alignment involves a philosophical, self examination of axiomatic assumptions such as ontology and epistemology. [9]

An aspect of this framework is positionality (CAELLI, RAY \& MILL, 2003) and how self is situated in the research process. Explicating and positioning self with regard to philosophical and theoretical ways of knowing and being are critical for the purposes of methodological rigor. I use the term research identity because it encompasses the collective dimensions by which a researcher is recognizable including how he or she positions self. Research identity is conceptualized as a set of beliefs and values that define the researcher at a point in time; it imparts a sense of adherence to a particular lens or framework or paradigm. Research identity is not a static entity because it is temporal and contextual in that it can change over time and shift with experiences. Accordingly, a research identity evolves throughout our careers. [10]

The beginnings of an inquiry are threaded throughout the research process, so we need to have some way to explicate them, to gaze inward before we can truly gaze outward. It has become accepted in the qualitative traditions that researchers need to scrutinize their own beliefs (COX, 2003; HERTZ, 1997; MACBETH, 2001). Reflexivity is a method to aid us in crystallizing the lens through which we approach research and view phenomena (CAROLAN, 2003). It is a method of locating and deconstructing the intersections of self as researcher, other, text and the social world (MACBETH, 2001). Engaging in a reflexive approach, and positioning self early in and continually throughout the research process can augment epistemological integrity and thus rigor. However, inherent within the published reflexive account is the risk that "writing fixes words" (ELIZABETH, 2008, paragraph 21). The poetic journey I perform here involves a risk that my identity will be interpreted as completed or my published story as finished in which they become hardened molds that can no longer shift. I provide the caveat that this performative piece is temporal and will continue on even after you read the last sentence. Although I would like to suggest that I have carved out and secured my research identity, I will not make that slippery assumption. 
Nevertheless, the current place that my journey has brought me is apprehensible. Only by explicating my journey to a research identity and illuminating my presuppositions, in large part through journaling and poetry, have I found a way to enter into my research with a positioning that is clear and a lens that is perceptible. [11]

\section{A Forethought: Poetry}

It is necessary to clarify the approach I take in this article because it veers away from the traditional format of academic and scientific writing. In this article I utilize poetry in combination with prose and photography. Poetry is quintessentially performative both ontologically and epistemologically. It is a way of knowing and being for the writer, but also asks the same of the reader. Poetry has acted as a way for me to understand more clearly what I'm thinking. I have often used poetry to conceptualize and to elicit an emotional and gut feeling of a particular phenomenon (e.g., LAPUM, 2008, 2006). As I have noted elsewhere (LEUNG \& LAPUM, 2005), the crafting of poetry for me (e.g., writing) can be fashioned as a way of knowing (RICHARDSON, 2000). It can be a source of knowledge, but also impart an aesthetic knowing that captures affect and context through personal telling (FURMAN, LANGER, DAVIS, GALLARDO \& KULKARNI, 2007). [12]

As I traveled along the journey to a research identity, I was continually journaling my experiences. Journaling can occur through multiple formats, but poetry is the way I am most comfortable with and is most revealing for me. Because poetry involves a writing process with no limits or boundaries (LAPUM, 2005; LEUNG \& LAPUM, 2005), it can take a format that is representative of the author's thinking at the time. My journey to a research identity was non-linear and disconcerting. I vacillated between ways of thinking and at times I was floundering. Poetry was able to render my journey into an emotional and articulate expression. Thus, in this article I felt that it was only appropriate to construct and impart my journey through poetry. [13]

I first presented a version of this poetical confession as an oral paper at a conference. The responses were engaging, and reinforced that others shared journeys to research identities filled with a medley of emotions-angst, apprehension, exasperation, and fortunately, enlightening moments of anticipation and exuberance. It was evident that a potential existed for others to benefit from listening to and engaging in a story that is all too commonly unspoken. [14]

Initially, I felt the spoken word format of my presentation could not be adapted to written word. Spoken word carries the ability to adjust your tone and speed, and express your emotions more openly. With intense commitment, I translated the spoken word into a written word format with hopes that the meaning would not vanish with the voice, or that the voice would not vanish with the written format. It is primarily written in a 1st person perspective in order to engage you closely and personally and enhance the aesthetic and moral sensibilities. Unlike traditional prose, the dialogical nature of poetry (LAPUM, 2005) opens up and leaves room for the reader to enter into the journey. As well, you will notice a conversational 
quality to the writing, which is an attempt to engage speed and tone and the natural involvement of an audience. As such, this article is a performative manifestation of my journey to a research identity. I invite you to read this piece out loud and in a way that you engage in it emotionally and become wrapped up in the experience, and that you possibly feel the sense of urgency with which it was written. [15]

\section{Unearthing the Performative}

The beginning of my story is difficult to demarcate clearly as my research identity has many dimensions-inflictions-transformations-revelations. A discussion of identity conjures up a number of various types. Traditional conceptions of identity are prevalent today, purporting a monological characterization that is linearly developed and stable over time (MISHLER, 1999). But identities are not static; they are multilayered and grounded in and continually evolve with our situated and lived experiences (BURY, 1982; GUBA \& LINCOLN, 2005; ORONA 1990; WEINREICH, 2003). The journey to a research identity that I restory here is framed in terms of a dialogical approach in which it is continually constructed through relations to others and shaped by experiences in the world (FRANK, 2005; SAMPSON, 1993; SHOTTER, 1999). As such, identity is dynamic and fluid (NELSON, 2001), involving a process of defining and understanding who one is (KASHIMA \& FODDY, 2002; TAYLOR, 1994). [16]

My research identity did not spontaneously emerge, but is something that has been unfolding and is continuing to evolve. I had a practice-based life as a registered nurse before research grabbed me, before narrative pulled me in. And poetry, of all things, has been instrumental in allowing me to understand fully my research identity in the scientific and narrative world that I located myself for my doctoral studies. So ... who am I? What is my research identity? Although I could not definitively identify my research identity early on in this process, I quickly became aware that I could not conform to the tenets of the dominant discourse of biomedical research - the one that tends to value an objective stance and attempts to subdue complexity. [17]

\subsection{Edging away from the dominant discourse}

For my purposes, I did not want to eschew science, but I wanted to engage in an inquiry that embraced a different way of knowing. Biomedicine is a science that underpins nursing (as well as other social health care practices) and is governed by principles of control, randomization and verification (MITCHELL, 2001). It is the dominant discourse in health care research. However, we are cautioned by ESTABROOKS (2001, p.283) that a "focus on scientific knowledge to the exclusion of other knowledge forms" is neither appropriate nor beneficial. I realized early that patients' experiences of technology in heart surgery could not be explored in an objective manner. Experience is quite indiscernible and I needed to engage in a method that accounted for subjectivity and complexity. [18] 
Narrative provided a method to get close to patients' experiences of heart surgery and the meanings they constructed of technology. Both narrative and poetry moved my doctoral inquiry forward, allowing me to engage in a scientific knowing that is informed by aesthetics and personal knowledge (CARPER, 1978), morality and emotions (RICHARDSON, 1994), and allowed for self to enter into the research. In exploring other epistemological avenues, I stepped out of the controlled environments of research and into that complex thing called—life. [19]

Science and traditions of biomedicine previously presided over my professional and academic life, but poetry surfaced unmethodically in the second year of my Doctoral program and has since been interwoven through all dimensions of my work. Poetry may have acted as a way to subconsciously fend off what Heidegger referred to as a forgetfulness of being (as cited in CONLE, 2000). By resisting the poetical side of my being, my way of thinking was more consistent with the dominant discourse of science. Initially this may seem suitable, at least from a traditional scientific stance, in which subjectivity is to be contained, but the knowledge that I am attempting to engage in is contextualized and is situated within narrative, and self cannot be absent (see Illustration 3). The performativity of a dominant discourse is its prescriptive nature that becomes embodied and shapes our identities (WINANCE, 2007), in ways that can be prereflexive.

Although discourse is always present, I became critically conscious of how I was incorporating the authorial voice of science into my identity as a researcher. However, for me, science without poetry is like a life in which self is not fully engaged.

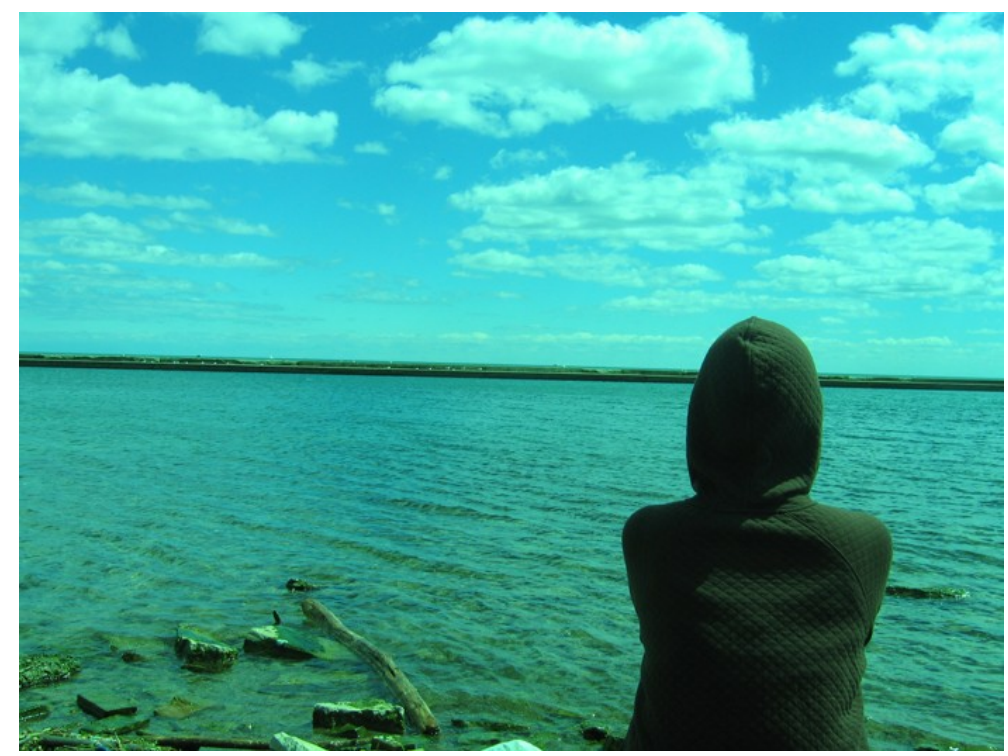

Illustration 3: Introspection (c) Gary C. BARJAROW, 2006 [20] 
Mere acknowledgment of self.

Traditional bracing of me.

Objectifying it. Compartmentalizing it. Pushing it out of my mind.

Burying it into the bottom of my being.

Nearly out of reach
unleashing "self" ...

uprooting that which is ingrained

understandings arising

truth

fading

notions of objectivity

dissipating

struggling to extricate self

engaging self

confusion looms heavily

—a way of being faltering

bridling biases

guarding the personal

—an illusion unsound

representing self without subsuming my essence

—an illusion faltering

a struggle to rid myself of me

vacillating between ways of thinking

cast,

into disarray

potent convictions to savor this immersion

hold strong

anticipating the demise of my struggle as though an end exists

fortunate

my thinking isn't paralyzed

gazing at this endless path further into the abyss I proceed unleashing

self

letting my story sway my next move

spiraling 


$$
\begin{aligned}
& \text { daunting } \\
& \text { exposed- }
\end{aligned}
$$

I gaze inward [21]

The undeniable struggle in the above poem was initially disturbing because I was unfastening myself from a dominant paradigm that I was comfortable with because of tradition, but uncomfortable with because it demanded a way of thinking and being that did not engage all facets of self. Within the dominant discourse of science, I am expected to step out of and suspend self. But self is not an entity that can be contained and sculpted in place. Like sand, it can be imprinted, molded, changed, with the shifting winds, sifting sands ... [22]

$$
\text { My thoughts, thinking, being }
$$

saturated with a history that seeps out of me without my conscious conscience thinking I can step out of this history like stepping out of my shoes, not likely not desirable.

The potency of history seared into "I"

historical consciousness

branded like a cow

I cannot think in isolation

I cannot understand without preunderstandings

a-self-quarantined-inexecutable

understandings—self-interpretations

not unescorted

prefigured, configured, we enter the circle

taking awareness of our standpoints

our situatedness

"our" self

grounding understanding in our self so we don't bypass the essence

a naked isolated self-such an illusion

co-authored by my history

my thinking cannot transcend from I

I cannot see from this place of nakedness because it does not exist beyond unvarnished interpretations from my detached disengaged self improbable.

—entering the circle-

It collapses. 
The "self" is missing.

Searching for these understandings of Truth.

Merely observing regularities.

Jumping out of self as though it were possible.

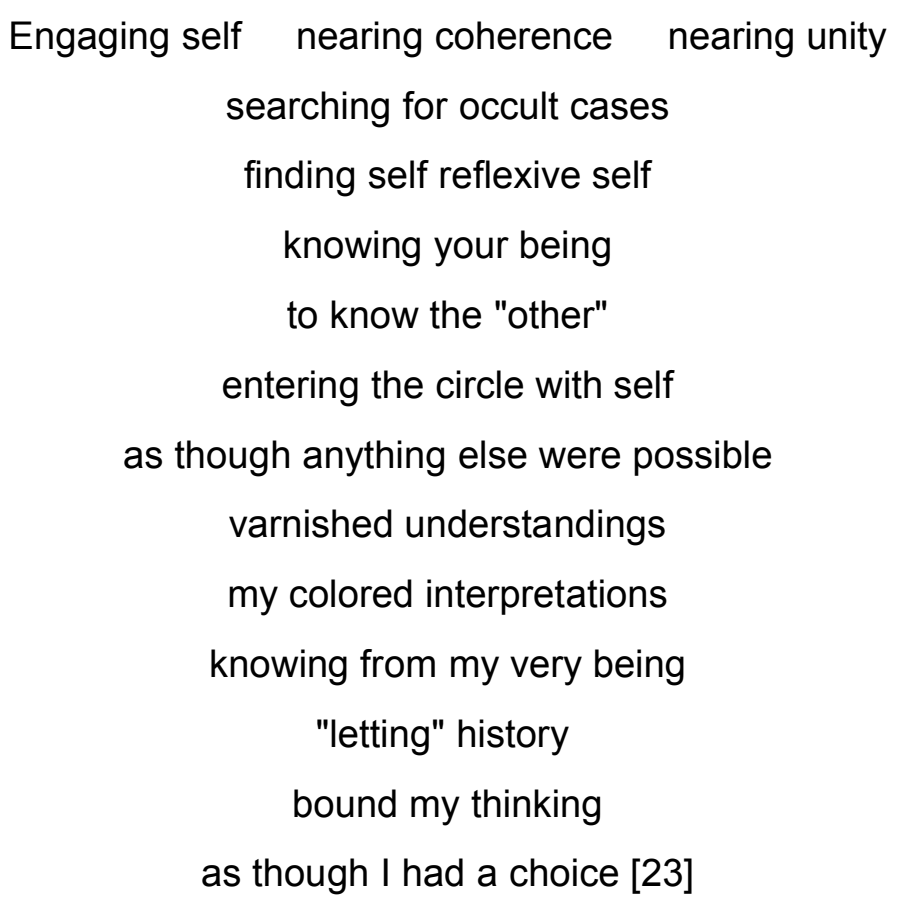

Moving away from the dominant discourse of biomedical research (but also taking note that I will always be within it), I considered closely subjectivity and the ways that an objective self as the researcher is improbable. I became more aware of the interpretive nature of research, and how self is implicitly interwoven and critical to the interpretations that are inherent to any exploration. I became leery of the epistemological foundations of the scientific method and ventured to adapt a science that took into consideration the idiosyncratic nature of human experiences. I unknowingly dropped into the world of postmodernism for a number of reasons including the following: a disquiet concerning modernistic appeals to objectivity; an intellectual pull to a science that attends to the aesthetic nature of knowing (CARPER, 1978); a personal appeal to allow for morality and emotions to be engaged (RICHARDSON, 1994); and lastly my gravitation to the arts. [24]

\subsection{Gravitating to postmodernism}

The credibility of grand narratives remains contentious in social worlds containing people who are not wholly uniform and who live within different contexts. A postmodern framework opens up space for local and particular narratives, as opposed to the totalizing nature of grand narratives that cannot realistically capture the complexity and unique aspects of human experience. LYOTARD (1984) suggested a turn away from the modernistic ways of knowing to a postmodern epistemology that revels in contextualized narratives. From this 
standpoint, knowing becomes partial and situational (RICHARDSON, 2000). Attending to local narratives (LYOTARD, 1984) allows access to the subjective and historical aspects of persons' experiences. This sat well for me at the time because I recognized that experience was not universal and for this reason grand narratives and theories cannot be legitimately generalized. Finally a place for stories, a place for me, at least I thought ... (see Illustration 4).

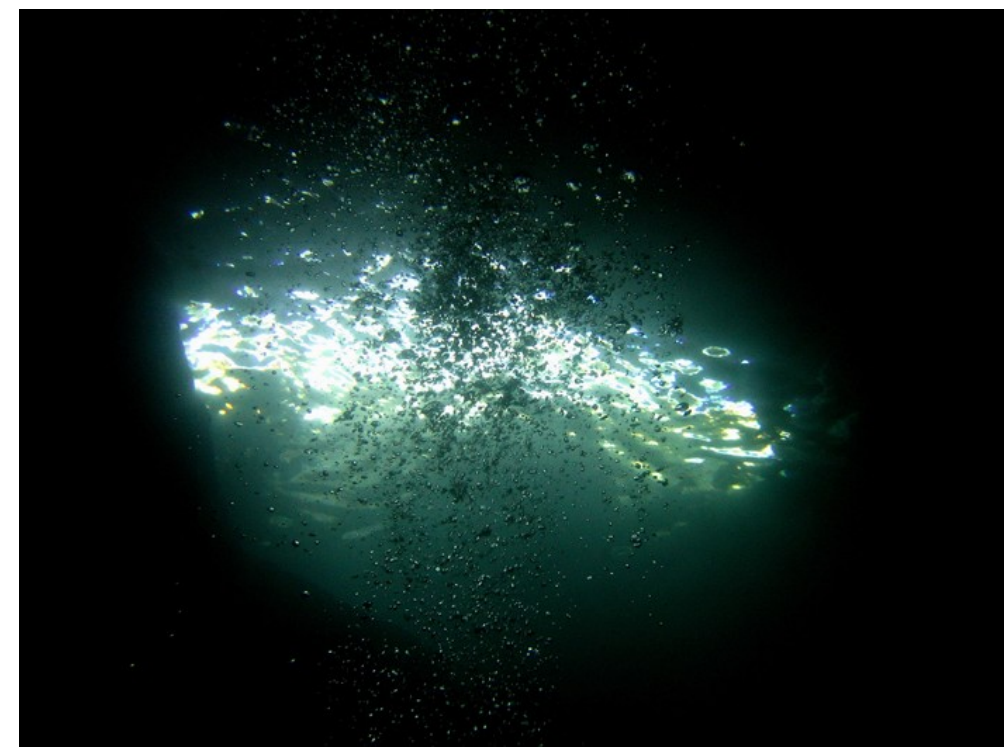

Illustration 4: Drowning @ Gary C. BARJAROW, 2005 [25]

$$
\begin{gathered}
\text { Drowning } \\
\text { floundering } \\
\text { drifting astray }
\end{gathered}
$$

floated quite purposefully into my alcove

my postmodern tendencies captured me

but not exhaustively

comfort found in the uncomfortable partial truths and localized nature of understanding-

grasping for the hand I see up through the layer of water into the blue sky

$$
\begin{gathered}
\text { gone } \\
\text { dissipating }
\end{gathered}
$$

my alcove turned into a burrow

something like the one that Alice got caught up in

but there was no white rabbit

leading me,

looking up through the green leaves of ivy 


\section{I rest my head back \\ breathe}

take a moment to dwell but only a moment dwelling within my forgetfulness in not within reach

dwelling in a trice

quite absurd

quite ironic when you think about it

quite unthinkable when you're caught up in the technological

how to disentangle myself from a web of profuse mindlessness

near heedless near forgetful near gone

mere surface activity you say

fading in and out of forgetfulness of being

is that possible

proper

the automatic thoughts are concealing

the whites of my eyes

revealing

I see the veins extending in the leaf feeding the ivy

a stranger to this ivy I am even though

I sit beside it everyday

sitting there to look pretty

how bland

how academic

my eyes begin to constrict

I realize the ivy is feeding my being

ridding my forgetfulness

recovering a remembering [26]

My journey has taken me in many directions and had me going in circles and retracing my steps. But it wasn't mere surface activity (CONLE, 2000). Each burrow and alcove I got caught up in led me to where I am now and provided me with the ability to rationalize my choices concerning my research identity. Actively engaging in and documenting this journey provided an audit trail of its reflexive nature and attested to the rigor of my philosophical and theoretical decision making. [27] 
Although I felt a pull to postmodernism and continue to value many of its tenets, I could not fully situate myself there. The equivocations of postmodernism were of concern because a clear structure from which to draw is not provided. Despite my appreciation for situated ways of knowing, I still had faith in some sense of realism. HUSSEY (2000) suggests that social practices (e.g., nursing) are based in realism, involving conventions of practice that guide intentional activities of decision making and behavior. If there were not some grand narratives or theories from which to frame knowledge construction and social practices, how could we function in our daily routines? What would we base our health care practices on in the domain of heart surgery if we did not have some sense of realism? LAWSON (1998) argues that partial regularities or patterns exist that are relatively enduring over a particular time and space. This does not negate the idea that social life is dynamic, nor does it claim that these patterns are certain and universal (LAWSON, 1998). Nor does it claim that we should carelessly apply them without judicious attention to context and the nuanced nature of human beings. [28]

Can my ways of knowing be both postmodernist and realist? The blurring of research identities is contentious. Can such seemingly contradicting paradigms even be commensurate with one another? Many scholars would equivocally say no. Others would suggest that paradigms may be commensurate if the axiomatic assumptions of each paradigm are similar (GUBA \& LINCOLN, 2005). Postmodernism and realism have more differences than similarities. However, are not the epistemologies and ontologies that underpin our social lives and practices blurred and temporal? Does not our ways of thinking and being and the knowledge we draw from depend on the issue at hand? The phenomenon we are studying? If we are attempting to determine the most appropriate health care or social practice, should it not depend on the specific problem we are concerned with? I'm still pondering ... [29]

As I moved on, I began to think that my research identity could not fit into one box, one paradigm, the socially-constructed taxonomies did not seem to fit my way of thinking and being. Was I just being epistemologically and ontologically difficult? [30]

\subsection{Tailor-made research identity}

The struggle was revealing

(un)concealing

a realization transpired

success materialized

I extricated myself from that which was driven into me

heavily imprinted on my thinking like those little ducklings imprinting on a human

but my being never gave in, it's done

complete 
circumspect

I now know what I am not

what I cannot be

the way I cannot think

my identity is making itself known to me

how coy it has been over the years

yet it has cropped up in such an un-sheepish way I can no longer cold-shoulder it because it has utterly embodied my being without reservation, I am it-

it is me

I know what it is not

but what is it

it's not complete

a sweepingly executed research identity is always half-done

half there

partially executed

partially known

who knows what's around the next corner

who knows what scientific revolution is going to throw my thinking into upheaval and make me long for

what-once-was

revolting against the research identity I had carefully carved out for myself

a carving

a place

an identity no longer tailor made for my story

always in motion

always unfolding

the whole enchilada ... like the apparition you can touch

an impervious possibility

I don't believe in THE TRUTH, but I believe in truth and truths and truthfulness

I don't believe in utter relativism, but I believe historicity and situatedness and interpretive and storied beings, and,

r-e-l-a-t-i-v-i-s-m?!

I believe in the dialogical

I believe in knowledge that is not set in stone 
although I like to imagine what Auguste Rodin's The Thinker is thinking about I feel saddened that he was left to think

indefinitely

bronzed in place

foreclosed in space

he marks me.

I believe the cornerstone of knowledge lies in stories

I don't believe in an objective and impartial and unbiased account, but I believe in stories that attempt to account for the subjective experience, but in telling does it not become objectified, by putting words to the experience, does it no longer become subjective, but objectified, it is now an object of my thought, just as what I am writing is an attempt to articulate my subjective experience to a research identity, but it is now an object of my thinking, but,

I-am-not-objective.

Can I still be a storyteller?

A narrative inquirer?

You know those people who push you and pull you and shape you and add more to you and take some away until you fit their mold, well I'm mold(less), but that doesn't mean I'm less.

Fit yourself in a category.

Associate yourself with a paradigm.

If I don't have a label

Then who am I?

Kind of like a cement truck dumping its haul upon me, becoming more of what it is and less of what I am, the cement freezes me in place, unable to evolve, stuck in that label I took on, I wish I hadn't labeled myself, categorized myself, now, if you took the water away

l'd just be calcium limestone and clay

Can I be a realist?

a pragmatist?

Can I be an interpretivist?

Can I be a narrativist?

Can I be them all?

Can I situate myself as a postmodernist?

at times

Can I be interested in experiences and still want to measure things?

Can I measure things and still be suspect of generalizations? 
Can I even comprehend statistical inferences and generalizations when the idiosyncratic nature of being is so saturated to my skin?

manifest in my thinking

my being-my beliefs

I'm open to understandings at all layers

they cross cut paradigms

like the person who arrived at a crossroad

purposefully walked off into the poppy field

Is that enough?

Can I let it fluctuate?

Can I be transparently researchably

(un)identified?

Can the blurring of my identities hack it?

Will it be torn apart? (see Illustration 5)

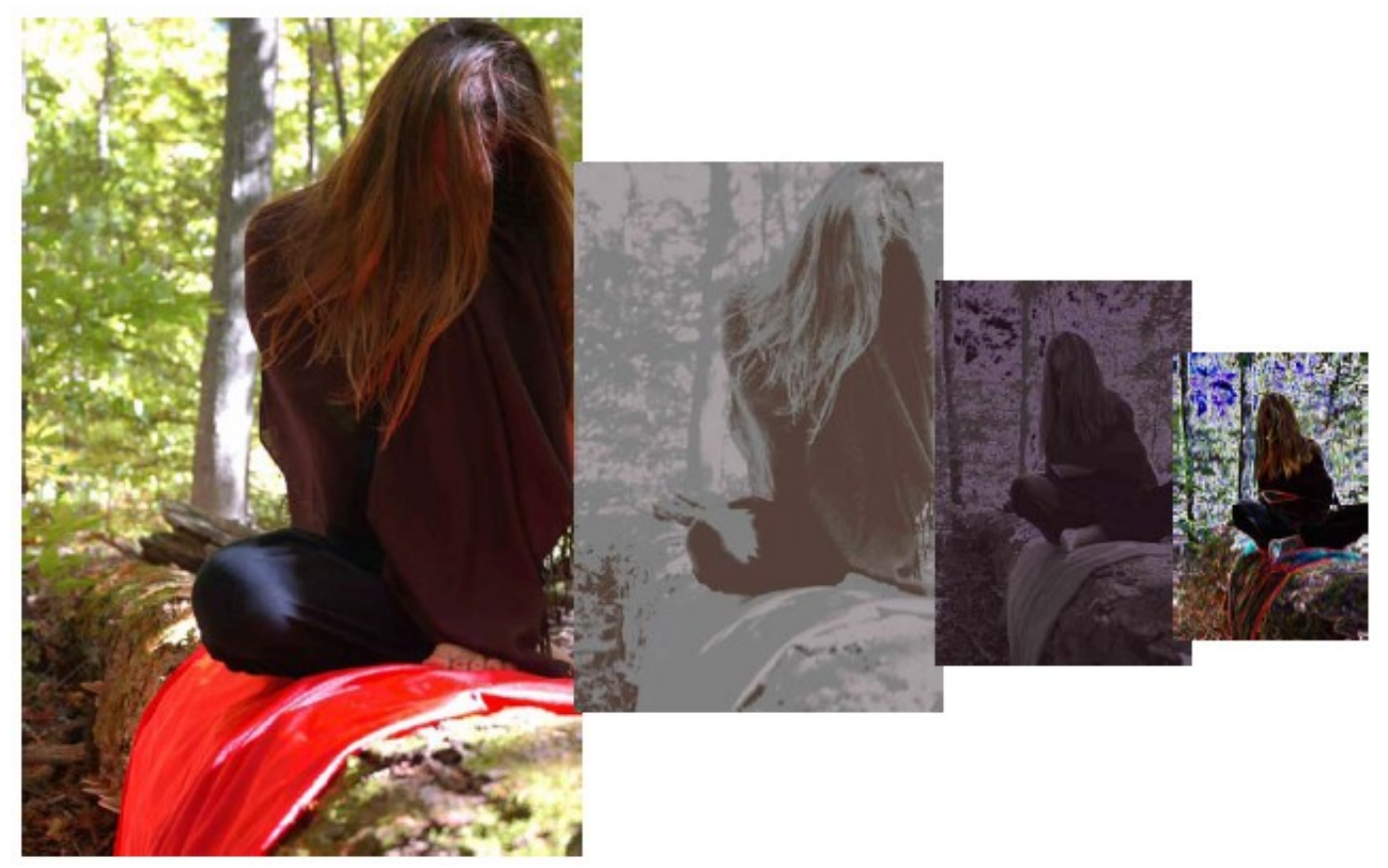

Illustration 5: Blur @ C Gary C. BARJAROW, 2007 [31]

hold on.

here we go

plunge into the realm

dive into the discourse

the plane lands 
there's no recourse

stop-wait

heed I dare say

keep in check

bear in mind

it is not an un-reality nor is it reality

it may be exhausting

exasperating

exhilarating

excruciating

and you may even excavate

a place in the world of

uncomfortable comfort

quite life-like

quite qualitative

not merely method

let's begin before

the end finds us

let me tell "my" story

oh! so ill-advised

my doesn't even exist

without thou

dare I be self indulgent

dare I not

dare I go blindly down this path without I

without thou

but don't get caught up in that

get caught up in this

my dialogical self

my ethnographic self

my personal self

my narrative self

what about my reflexive self?

too many selves 
which one will I be now, later

who was I before

which self

why selves

bracket them

bracket that

bracket!?!-

I'm lost

my "self" is missing

probably running for shelter, safety,

such a fallacy

to objectify the subjectivity of self

but we now know-

the self is more present than absent

"I" no longer exists

at least what I was before

static selves

we know better

I am thou

thou art I

you've seared my selves

and not just my professional self

I feel you

sense you

talking in my brain

I think we think you think I think we think

oh Mayhem

you've drawn me from simplicity

my fallacy

hung me on complexity

life

this is it

this is research

my struggle 
my journey

I will tell you no more, no less

I have jumped in without ruminating too much

without regret

a way of being into the unquiet

the mayhem

echoing steps of the Synchronicity Kid

poetically puffing out this story

because they asked me to turn my eyes inside out

inward, outward, inside out, outside in

where to begin

is this riveting

grab someone

do something

does this resonate

does this echo

"Tell someone I'm here"

I've written my address on my arm so if I'm lost too long

someone will hopefully return me

but I'm savoring this thrill as long as I can

have I hypnotized you yet?

I want to catch you up in my words

are you caught up

jump off the black and white

and into your thoughts

sear your being

more potent than a chromosomal defect that was transmitted to you from the gods of heredity and you feel guilty to damn your ancestors for the molecular mechanism that rests so bureaucratically in your DNA constituting part of,

who you are

marked nevertheless

because you marked me too

spiraling

spiraling 
spiraling

racing

can't stop thinking

unhinged from my thinking

too much for a thought

coherent at least

my head flops back in the cab-

the thoughts are sinking in

knotting my stomach

I can't think anymore

the spiraling is getting faster

hurts my head

affects that thing I feel through the bits of my body, pulsating

leaving this hole right in the solar plexus

I'm not predetermined

I can't always predict

I am not static

If I situate myself there,

I realize I'm not sure where there is, anymore

don't leave the other hopelessly predetermined, jump in

engage

don't foreclose

spiraling

walking onto the plane

sitting down letting go letting in giving in

I breathe-

I'm not ready to be cured and,

I quite don't know if a cure exists or what a cure would be

cure this whirlwind in my head

it is embodying me

or I have embodied it

overtaking, overcome the tensions in my head

I am writing a poetical confession of my journey

and I ask myself in your echoed voice 
"What does it matter anyway?"

Where do I go from here? I'm not foolish enough to think that unvarnished simplicity will ever capture my identity or that I can just coast through without clearly bringing forth my research identity. Labels, categories, I may resist, but something sits well for me, something draws me in, something frames my thinking. How can I untwist what may seem to be a convoluted mess? Suffice to say, the temporal nature of my research identity continues on. The performative grabs on to stories, uncoiling the convolution, but preserving complexity. [32]

\subsection{A trial curtain call}

Her uncertainties will never be certain

the knowledge she strives for is not static

nor does it foreclose on the one telling

she celebrates a knowing that does not exalt boundaries

a knowing that is not cemented in place

like The Thinker who was sculpted in bronze and left to meditate-

She celebrates a bound-less being

that can shift and change

a final act does not seem to exist

she has surrendered her search for, the Truth

but still has an aspiration for truth

the acid test has been blurred

conclusiveness replaced

by uncertainty

possibility

she is still wrapped up in

understanding

dialogue

nearing closer to reality

but never fully capturing it

she has learned to feed

off of the (un)painted

(un)sculpted

an un-fixing of mere watching

becoming part of the picture 


\author{
What's the prognosis you say \\ you think she's lost \\ she's not
}

she's finding her way with stories [33]

The wanderings and wonderings to secure a research identity in which I initially felt lost and confused, and admittedly feel perpetually tentative and wavering (but not irrevocably wayward) resulted in a journey that dropped me at a narrative epistemology-knowledge and knowing that is constructed through and revels in stories and storytelling. There is a part of me (my discursively-driven scientific self) that still wants to be able to clearly find that objective reality, the Truth, to have a sense of unquestionable understanding of whatever I study or the way I practice as a nurse. But, that is not life, that is not many of the social science phenomena we attempt to understand and examine. The phenomena that we study can be complex, messy, and textured (LAW, 2004). Reality at times can be elusive and vague (LAW, 2003). I made the methodological decision to let complexity breathe ... (see Illustration 6).

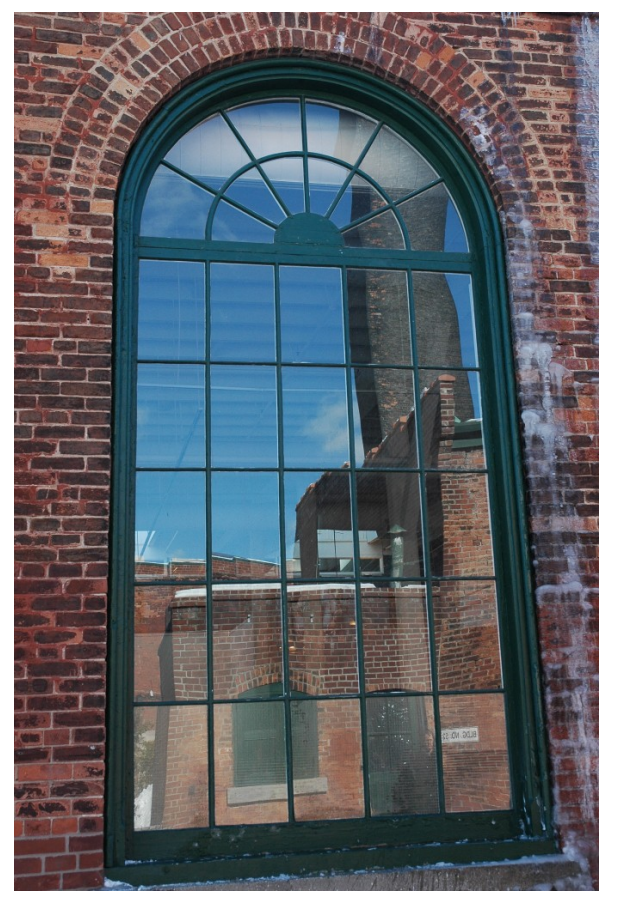

Illustration 6: Letting complexity breathe @ Gary C. BARJAROW, 2008 [34]

If I could encounter a pathway

beyond a doubt

rendering ambiguity irrelevant. 
If I could encounter a pathway

that is palpable

irrefutable

indisputable

quite suitable to the immutable-

$$
\text { I might }
$$

Irreverently captured by imperialism-

logics that spiral

sometimes from what can be,

an unbalanced axis

ontological deprivation

entangled in stability

repeatability

the predictabilities

a castle's permeability

revealed in its fallibility

life teased apart

from reverie

realizing I'm only a stone's throw from veracity

but the space from here to there is far

from systematically calculable

covered with kaleidoscopic cobblestones

clogged with so many unknowns

dis-comfort in complexities

discomfort fervently disturbing

the often invisible visibilities

only unveiled in the intricacies

and broken probabilities

my vice laid bare-an identity found

I deliberately,

purposefully 
forget-

how to untangle the textured mess

letting the elusive rest

finding meaning

in what seems to be a wreckage

at first glance

nonetheless [35]

There may be concrete realities associated with social science phenomena, such as those manifest in the operative procedures of heart surgery and the tangible evidence of the opening of the chest and the resultant incision and marked body. However, when examining phenomena associated with human experience (such as patients' experiences of technology in heart surgery), conceptions of reality and peoples' ways of being are not as objective or absolute. I made the decision to begin with an ontology of experience that is relational and continuous (CLANDININ \& ROSIEK, 2007) and linguistic (ALLEN \& CLOYES, 2005). The most basic and essential human reality is that of experience (CLANDININ \& ROSIEK, 2007). Experiences are not mere occurrences or events that happen to people (ALLEN \& CLOYES, 2005). These are indeed just that-events or occurrences. A basic ontological assumption underpinning my research is that experience involves a personally encountered and perceived occurrence, situation or event (ALLEN \& CLOYES, 2005). To experience technology and its many dimensions in heart surgery, an individual must encounter or perceive-be it in a cognitive, physical, verbal, actual, or imaginative manner. ALLEN and CLOYES (2005, p.103) state: "Experiential accounts are narratives, if we are clear that we are studying how they talk, then we can treat these accounts more rigorously by asking more questions, not just about they said, but why they said it that way." As such, research claims are not just a summary of what participants say, but a linguistic and historical examination of how stories unfold and why they unfold in a certain ways. And for me, I have accepted and engaged the complexities of phenomena by yielding to the epistemological nature of narrative. Stories allow for complexity to breathe without giving way to a disappearance of narrative understanding. [36]

Narrative is a way for individuals to make sense of and bring meaning to the complexity of their experiences, both for research participants and researchers. Thus, when exploring patients' experiences of technology in heart surgery, I employ narrative as an epistemological stance and as a way to enter into the researcher-participant relationship. My research identity in the narrative milieu has moved me to the ethics of storytelling and research. Early on, FRANK's $(2004,2005)$ narrative work concerning a dialogical approach to research captivated me. I wanted to be engaged in research that did not just construct and accumulate more knowledge and evidence, but was moral and dialogical. BAKHTIN (1984) sums up the effects of a monologic approach as: 
"something totally quantified, measured, and defined to the last detail: all of you is here, there is nothing more in you, and nothing more to be said about you. He felt himself to be hopelessly predetermined and finished off, as if he were already quite dead, yet at the same time he sensed the falseness of such an approach" (p.58). [37]

It is quite sad that research participants, storytellers, can feel this way. For this reason, I engage in a dialogical approach to research which "begins with recognition of the other's unfinalizability ... [and] depends on perpetual openness to the other's capacity to become someone other than whoever she or he already is" (FRANK, 2005, p.967). Henceforth, as I engage further in narrative inquiry, I will take BAKHTIN and FRANK'S words to heart, and I will not objectify and foreclose on research participants, storytellers. Nevertheless I will still attempt to understand their temporal and contextual realities through their stories. But I will not foreclose on a sense of a futurity, a sense of becoming. [38]

\subsection{Performative: The "bottom" line}

I return to the purpose of this article, which was to enact my performative journey to a research identity. I performed the journey and opened up ways to engage in reflexivity. I not only self-examined the spaces I lingered, but showed how and why my journey moved forward and how I was discursively driven. To enact this journey in a performative way strengthened the identity I have crafted because I am aware of where I have come from and conscious that this historical situatedness has marked me. My research identity is not a neatly packaged entity, but inhabits a blurring of spaces. Granted, I will always be shaped by a discourse of biomedicine and the socially constructed taxonomies that tend to influence an a-temporal position. Although discourse can imprison and restrict, if we are conscious and critical of its performativity, it can also empower and support (WINANCE, 2007). The spaces I inhabit may call forth particular aspects of my identity at moments in time and we need to open authentically ourselves to this epistemological and ontological condition of temporality. There is a call to critically consider the blurring of research identities because it is more analogous to human nature and social practices. The time is now to explore creatively how the blurring of identities can play out in our work and how this can be accounted for in the research process without our work being invalidated. I am not naïve enough to think this idea will not be scholarly critiqued, but I welcome that, because it will move me forward, require me to continue performing the performative. It may be less bothersome to subvert to tradition, but it is more gripping and life-like to consider the unfamiliar path. If you feel the pull to consider it, refer back to Illustration 2. At the very least the path is unfamiliar, intimidating, less traveled, and incalculable. At times, it is jarring and paralyzing. But-it awakened me to life and research that is more reflective of our temporal and blurred ways of being and knowing. [39]

To truly enact performativity as more than a theory requires researchers to anticipate change and shift with the spaces they inhabit and the phenomena they study (MARKUSSEN, 2005). We are not static beings with identities that are carved out and sit idle. Research identities are temporal. The fluid and temporal 
nature of our identities asks us to be in a constant state of rehearsal with a preparedness to enact its performativity. Although we need to be aware of our positions, we need to be prepared to change, sharpen them, and grow into them. It is inevitable that we become marked and mark others everyday. [40]

Performativity through poetry lends itself to a blurring and temporal nature of research identities. It is through the discursive journey that identities are built. "A performative is that discursive practice that enacts" (BUTLER, 1993, p.13). As such, the journey not only performs, but constitutes one's research identity. A performative social science is shifting the boundaries of research and opening up dissemination methods in artistic ways (JONES, 2007). Weaving together the arts and the sciences creates a synergistic effect that can enhance the underlying epistemologies of our research (LAPUM, 2005). I believe that performativity can lessen the gap between research and social life and health care practices (or other social practices). The identity(ies) I continually enact are dynamic and engage a dialogical space. To draw upon FRANK (2005), I have recognized my own unfinalizability. [41]

\subsection{My unfinalizability}

Getting caught up in

tracing my journey

to an identity

one harmonious with my being and,

to the reality of

real life

whatever that may be,

knowing now,

that it won't bottle me up

or make me less than what I am

more of what it is

hoping I find it

or that it finds me soon, since

thriving that feeling of being lost can only last for so long

some say at least

but I now know

despite writing it in stone

wherever I situate myself is only temporary

a makeshift

for what I will become [42] 
With each new experience, with every person who challenges me, with each research participant whom I engage, with every storyteller who tells me their story, with each poem I craft, with each story I live, with each oblique sideways glance directed my way-I shift, I change, I vacillate, I flesh out and grow into my identity. My research identity cannot be summed up more than I have already, because it is still on its journey, and as I have discovered, always will be.

Although I have made great strides, I feel I am never far from where I started, but just with a different lens, a different positioning, and Feet That are Wetter (see Illustration 7).

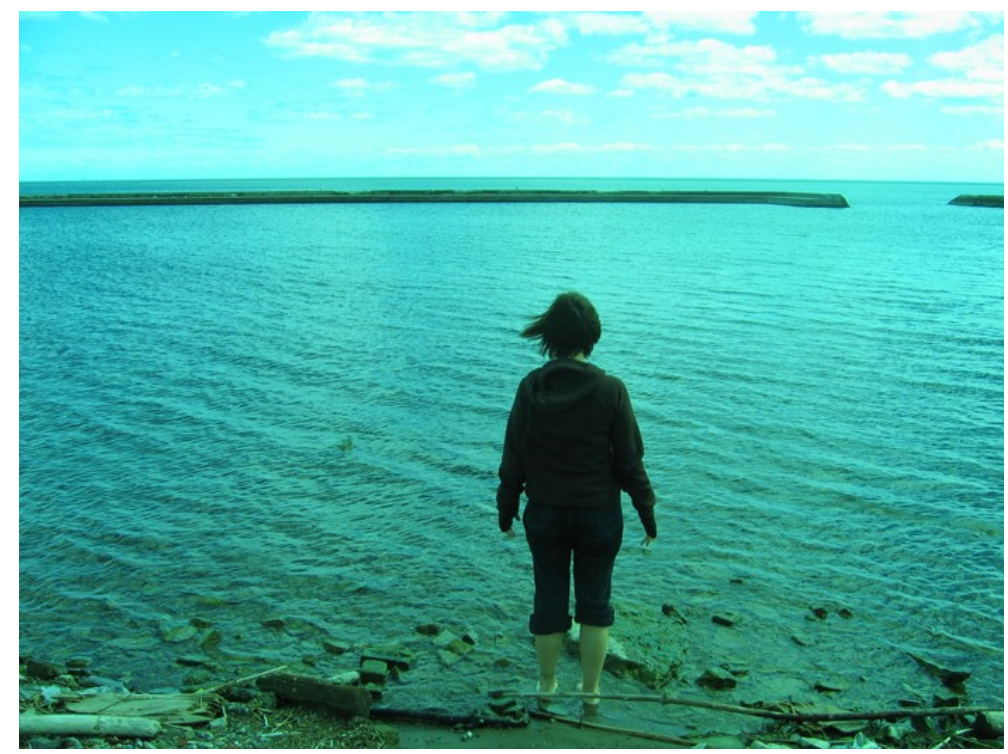

Illustration 7: Feet that are wetter ( ) Gary C. BARJAROW, 2006 [43]

In bringing this article to a close, I am not suggesting that my journey is over or that my research identity is finalized, that I have found a place of comfort wherein to wholly situate myself. I actually have an uncomfortable feeling about bringing this to an "end" at all, but positioning self in research is expected and critical. It provides a point of departure, a frame from which to guide you, and imparts to the audience the lens through which you are interpreting and engaging in your research. Nevertheless, I feel a sense of gnawing distress that change is never far. [44]

I leave you with a poem that strongly frames my research. I feel it is a framing, at this moment at least, that won't change too much over the years. This poem represents my awakening from the ingrained nature of monological ways of knowing, and morally reminds me of what I do not want to do to research participants who tell me their stories, and what I do not want to do to myself as the researcher, as a person. [45] 


\author{
this self \\ this individual \\ supposedly contained, \\ within the confines of \\ the physicality of my body \\ bound tightly \\ separated from other entities \\ as though singularity reigns \\ its essence \\ somewhere \\ in there \\ locked up
}

as though with a certain question

a proper framing

my essence would seep out

giving way

to a collapsing of all that I am

revealing my inner core

like drilling a hole in the protective cage that protects the inner core of who I am

$$
\text { and self }
$$

literally draining out

for you to analyze

(un)cover the cryptic nature of my soul

foreclosing on all that I am and,

might have been

dangling my will as I step forward

$$
\text { Left- }
$$

In Mid-step 


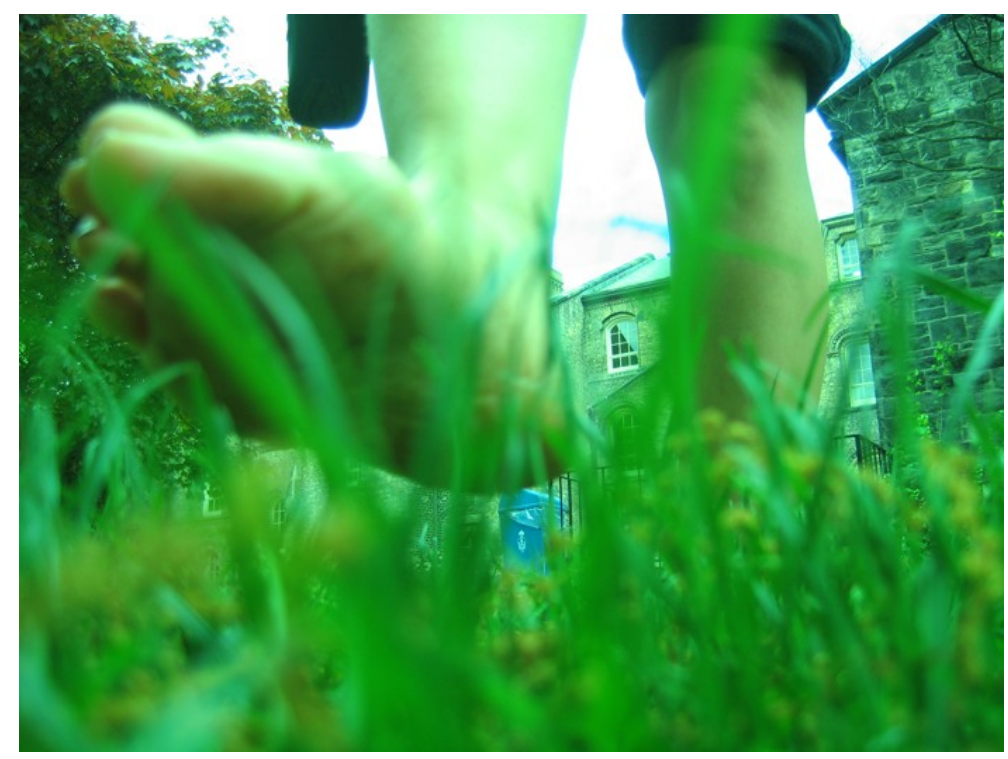

Illustration 8: Left in mid-Step @ Gary C. BARJAROW, 2006 [46]

\section{Acknowledgments \& Attribution Statements}

The poetry herein was crafted by the author of this article.

The creative and imaginative photography by Gary C. BARJAROW is very much appreciated and was co-produced with the author for the specific purposes of this article. The photographs are reproduced with permission.

There are so many people and so many voices that contributed to my thinking, so if you heard yourself in these pages, thank-you for your inspiration. Most notable is Claire LAPUM's artistic work in the forest, which was mesmerizing and thought provoking. Without the progressive cultivation of my doctoral supervisor Dr. J. ANGUS and my PhD committee members Dr. E. PETER and Dr. J. WATTWATSON the experiences that led to the writing of this article would not have been able to occur. The insightful dialogue that occurred between my colleague D. LEUNG and myself incited the possibility for this article. I also acknowledge my doctoral education funding sources that have allowed me to commit myself to my PhD studies, including: Heart \& Stroke Foundation Nursing Research Fellowship; and the Strategic Training Program for Cardiovascular Nurse Scientists, a partnership between the Canadian Institutes of Health ResearchInstitute of Circulatory and Respiratory Health and the Heart and Stroke Foundation. A version of this paper was first presented at the Narrative Matters 2006 conference in Nova Scotia, Canada. 


\section{References}

Allen, David \& Cloyes, Kristin (2005). The language of "experience" in nursing research. Nursing Inquiry, 12(2), 98-105.

Bakhtin, Mikhail (1984). Problems of Dostoevsky's poetics (E.T.C. Emerson, trans.). Minneapolis: University of Minnesota Press.

Bury, Michael (1982). Chronic illness as biographical disruption. Sociology of Health and IIIness, 4(2), 167-182.

Butler, Judith (1993). Bodies that matter: On the discursive limits of "sex". New York: Routledge.

Caelli, Kate; Ray, Lynne \& Mill, Judy (2003). "Clear as mud": Toward greater clarity in generic qualitative research. International Journal of Qualitative Methods, 2(2), Art. 1,

http://www.ualberta.ca/ iiqm/backissues/pdf/caellietal.pdf [Date of access: November 1, 2004].

Carolan, Mary (2003). Reflexivity: A personal journey during data collection. Nurse Researcher, 10(3), 714.

Carper, Barbara (1978). Fundamental patterns of knowing in nursing. Advances in Nursing Science, 1(1), 13-23.

Clandinin, Jean \& Rosiek, Jerry (2007). Mapping a landscape of narrative inquiry: Borderland spaces and tensions. In Jean Clandinin (Ed.), Handbook of narrative inquiry: Mapping a methodology (pp.35-76). Thousand Oaks: Sage.

Conle, Carola (2000). Thesis as narrative or "What is the inquiry in narrative inquiry?" Curriculum Inquiry, 30(2), 189-214.

Cox, Susan (2003). Stories in decisions: How at-risk individuals decide to request predictive testing for Huntington disease. Qualitative Sociology, 26(2), 257-280.

Denzin, Norman K. (2001). The reflexive interview and a performative social science. Qualitative Research, 1(1), 23-46.

Denzin, Norman K. \& Lincoln, Yvonna S. (2000). The discipline and practice of qualitative research. In Norman K. Denzin \& Yvonna S. Lincoln (Eds.), Handbook of qualitative research (2nd ed., pp.128). Thousand Oaks: Sage Publications Inc.

Elizabeth, Vivienne (2008). Another string to our bow: Participant writing as research methods. Forum Qualitative Sozialforschung / Forum: Qualitative Social Research, 9(1), Art. 31, http://www.qualitative-research.net/fqs-texte/1-08/08-1-31-e.htm [Date of access: February 15, 2008].

Estabrooks, Carole (2001). Research utilization and qualitative research. In Janice Morse, Janice Swanson \& Anton Kuzel (Eds.), The nature of qualitative evidence (pp.275-298). Thousand Oaks: Sage Publications.

Frank, Arthur (2004). The renewal of generosity: Illness, medicine, and how to live. Chicago: The University of Chicago Press.

Frank, Arthur (2005). What is dialogical research, and why should we do it? Qualitative Health Research, 15(7), 964-974.

Furman, Rich; Langer, Carol; Davis, Christine; Gallardo, Heather \& Kulkarni, Shanti (2007). Expressive, research and reflexive poetry as qualitative inquiry: A study of adolescent identity. Qualitative Health Research, 7(3), 301-315.

Guba, Egon \& Lincoln, Yvonna (2005). Paradigmatic controversies, contradictions, and emerging confluences. In Norman K. Denzin \& Yvonna S. Lincoln (Eds.), The Sage Handbook of Qualitative Research (3rd ed., pp.191-215). Thousand Oaks: Sage Publications.

Hammersley, Martyn \& Atkinson, Paul (1989). Writing ethnography. In Martyn Hammersley \& Paul Atkinson (Eds.), Ethnography: Principles in practice (pp.205-232). New York: Routledge.

Hertz, Rosanna (Ed.) (1997). Reflexivity \& voice. Thousand Oaks: Sage.

Hussey, Trevor (2000). Realism and nursing. Nursing Philosophy, 1, 98-108.

Jones, Kip (2006). A biographic researcher in pursuit of an aesthetic: The use of arts-based (re)presentations in "performative" dissemination of life stories. Qualitative Sociology Review, 11(1), 66-85. 
Jones, Kip (2007). How did I get to Princess Margaret? (And how did I get her to the world wide web?). Forum Qualitative Sozialforschung / Forum: Qualitative Social Research, 8(3), Art.3, http://www.qualitative-research.net/fqs-texte/3-07/07-3-3-e.htm [Date of access: October 15, 2007].

Kashima, Yoshihisa \& Foddy, Margaret (2002). Time and self: The historical construction of the self. In Yoshihisa Kashima, Margaret Foddy \& Michael Platow (Eds.), Self and identity: Personal, social and symbolic (pp.181-206). New Jersey: Lawrence Erlbaum Associates, Publishers.

Lapum, Jennifer (2005). Women's experiences of heart surgery recovery: A poetical dissemination. Canadian Journal of Cardiovascular Nursing, 15(3), 12-20.

Lapum, Jennifer (2006). Until my time of death. Canadian Medical Association Journal, 174(12), 1749-1750.

Lapum, Jennifer (2008). Residuals of death. Qualitative Inquiry, 14(2), 233-234.

Law, John (2003). Making a mess with method. Lancaster, UK: Centre for Social Studies, Lancaster University, http://www.comp.lancs.ac.uk/sociology/papers/Law-Making-a-Mess-with-Method.pdf [Date of access: January 10, 2007]

Law, John (2004). After method: Mess in social science research. London: Routledge.

Lawson, Tony (1998). Economic science without experimentation. In Margaret Archer, Roy Bhaskar, Andrew Collier, Tony Lawson \& Alan Norrie (Eds.), Critical realism: Essential readings (pp.144-169). London: Routledge.

Leung, Doris \& Lapum, Jennifer (2005). A poetical journey: The evolution of a research question. International Journal of Qualitative Methods, 4(3),

http://www.ualberta.ca/ iiqm/backissues/4_3/pdf/Leung.pdf [Date of access: December 1, 2005].

Lyotard, Jean-Francois (1984). The postmodern condition: A report on knowledge (Geoff Bennington \& Brian Massumi, Trans.). Minneapolis: University of Minnesota Press.

Macbeth, Douglas (2001). On "reflexivity" in qualitative research: Two readings, and a third. Qualitative Inquiry, 7(1), 35-68.

Manderson, Lenore; Bennett, Elizabeth \& Andajani-Sutjahjo, Sari (2006). The social dynamics of the interview: Age, class, and gender. Qualitative Health Research, 16(10), 1317-1334.

Markussen, Turid (2005). Practising performativity. European Journal of Women's Studies, 12(3), 329-344.

Mishler, Elliot (1999). Storylines: Craftartists' narratives of identity. Cambridge, Massachusetts: Harvard University Press.

Mitchell, Gail (2001). Pictures of paradox: Technology, nursing, and human science. In Rozzano Locsin (Ed.), Advancing technology, caring, and nursing (pp.22-40). Westport, Conneticut: Auburn House.

Nelson, Hilde (2001). Damaged identities: Narrative repair. Ithaca: Cornell University Press.

Noy, Chaim (2003). The write of passage: Reflections on writing a dissertation in narrative methodology. Forum Qualitative Sozialforschung / Forum: Qualitative Social Research, 4(2), Art. 39, http://qualitative-research.net/fqs-texte/2-03/02-03noy-e.htm [Date of access: January 4, 2006].

Orona, Celia (1990). Temporality and identity loss due to Alzheimer's disease. Social Science \& Medicine, 30(11), 1247-1256.

Richardson, Laurel (1994). Writing as a method of inquiry. In Norman K. Denzin \& Yvonna S. Lincoln (Eds.), The handbook of qualitative research (1st ed., pp.516-529). Thousand Oaks: Sage Publications.

Richardson, Laurel (2000). Writing: A method of inquiry. In Norman K. Denzin \& Yvonna S. Lincoln (Eds.), Handbook of qualitative research (2nd ed., pp.923-948). Thousand Oaks: Sage Publications.

Sampson, Edward (1993). Celebrating the other: A dialogical account of human nature. New York: Harvester Wheatsheaf.

Sandelowski, Margarete (2000). Whatever happened to qualitative description? Research in Nursing \& Health, 23, 334-340.

Shotter, John (1999). Life inside dialogically structured mentalities: Bakhtin's and Voloshinov's account of our mental activities as out in the world between us. In John Rowan \& Mick Cooper (Eds.), The plural self: Multiplicity in everyday life (pp.71-92). London: Sage Publications. 
Taylor, Charles (1994). The politics of recognition. In Amy Gutmann (Ed.), Multiculturalism: Examining the politics of recognition (pp.25-73). Princeton, New Jersey: Princeton University Press.

Weinreich, Peter (2003). Identity structure analysis. In Peter Weinreich \& Wendy Saunderson (Eds.), Analysing identity: Cross-cultural, societal and clinical contexts (pp.7-76). London: Routledge.

Winance, Myriam (2007). How speaking shapes person and world: Analysis of the performativity of discourse in the field of disability. Social Theory \& Health, 5, 228-244.

\section{Author}

Jennifer $L$. LAPUM is a registered nurse and a $\mathrm{PhD}$ candidate at the Lawrence S. Bloomberg Faculty of Nursing, University of Toronto. Her doctoral study is a narrative inquiry of patients' experiences of the technological in heart surgery. She has an scholarly passion for blending the arts and the sciences.
Contact:

Jennifer L. Lapum

Lawrence S. Bloomberg Faculty of Nursing University of Toronto

155 College Street, suite 130, Toronto, ON, M5T 1P8, Canada

E-mail: j.lapum@utoronto.ca

\section{Citation}

Lapum, Jennifer L. (2008). The Performative Manifestation of a Research Identity: Storying the Journey Through Poetry [46 paragraphs]. Forum Qualitative Sozialforschung / Forum: Qualitative Social Research, 9(2), Art. 39, http://nbn-resolving.de/urn:nbn:de:0114-fqs0802392. 